The Chittagong Univ. J. B. Sci., Vol. 6(1 \&2):77-86, 2011.

\title{
INVESTIGATION OF ETHNOMEDICINAL PLANTS OF SUBARNACHAR IN NOAKHALI, BANGLADESH.
}

S. B. UDDIN ${ }^{1 *}$, NOOR HASSAN SAJIB ${ }^{1}$ AND MD. MANZURUL ISLAM ${ }^{1}$

Department of Botany, University of Chittagong, Chittagong-4331, Bangladesh

\begin{abstract}
Subarnachar is one of the traditional and promising upazilla in Noakhali district of Bangladesh. A survey of ethnomedicinal plants of the area was conducted from December 2009 to August 2011. The present study records 84 species under 75 genera in 47 families which is known to be used for the treatment of 34 diseases/illness. Field observations and discussion with local informants revealed that the ethnomedicinal plant species and traditional knowledge of the area is at great risk because of many threats including habitat destruction, agricultural advancement, and excessive collection of plants, industrialization and urbanization. It is very essential to document these plant use information before their disappearing.
\end{abstract}

Key words: Ethnomedicinal plants, Subarnachar, Noakhali, Bangladesh.

\section{INTRODUCTION}

From time immemorial man has been dependent on nature for survival. This dependency has led the primitive people living in close harmony with nature to evolve a unique system of knowledge about utilization of ethnomedicinal plant by way of trial and error. Traditionally this treasure of knowledge has been passed on from generation to generation without any written documents and is still retained by various tribes and old people-around the ecosystem. It is essential that the knowledge now available with local and tribal people is documented and integrated with modern scientific values before it gets entombed with the culture that gave birth in Bangladesh.

Subarnachar is one of the renowned upazilla in Noakhali district of Bangladesh occupying an area of 576.14 sq.km. The soil of this area is soft and saline (Mahmud 2007). Canals, ponds and agricultural lands become dried in summer whereas most of the areas are flooded in rainy seasons. As a result the ethnomedicinal plants of this area are at great risk. The people of the study area have not only preserved naturally occurring variability but have practiced

*Corresponding author :roben68@gmail.com 
selection for medicinal and economic characters and for wide range of biotic stresses. The documentation of local knowledge of specific plants along with germplasm maintenance declared immense values in this study. Interestingly there was no previous citation of such survey in Bangladesh. Therefore, the present investigation was under taken to investigate the ethnomedicinal plants of Subarnachar.

\section{MATERIALS AND METHODS}

The present ethnomedicinal investigations have been carried out in Subarnachar upazilla which lies between $22^{\circ} 38^{\prime}$ and $22^{\circ} 45^{\prime}$ North and $91^{\circ} 20^{\prime}$ and $90^{\circ} 58^{\prime}$ East. Subarnachar is bounded by Companiganj and Noakhali Sadar upazila on the north, Hatiya upazila on the south, Sandwip island on the east, Ramgati upazila on the west (Mahmud 2007).

In present study data have been documented in the area by following the field interview, plant interview and group interview techniques (Alexiades 1996) from December 2009 to August 2011. During the field interview, the information has been noted in the documentation data sheet. In addition audio recordings have been made with a digital voice recorder. The interview is a dynamic process involving spoken interactions between two or more people (Alexiades 1996). All the information regarding plant species, habit, habitat, local names and uses has been documented. Ethnomedicinal information were also obtained through informal interviews following semi structured and structured techniques from knowledgeable individual's, particularly kabiraj (local herbalist) and elderly people.

All voucher specimens have been collected during documentation. All the specimens have been pressed, dried and prepare herbarium specimens preserved in the Chittagong University Herbarium (CTGUH). The specimens have been identified consulting with the experts, through several herbarium studies by comparing herbarium specimens and through studying several available literatures. The description have been compared with Hooker (1872-1897), Prain (1903), Hassan (1971), Heinig (1925), Encyclopedia of Flora and Fauna of Bangladesh, Vol. 6-10. 


\section{INVESTIGATION OF ETHNOMEDICINAL PLANTS OF SUBARNACHAR IN NOAKHALI, BANGLADESH}

\section{RESULTS AND DISCUSSION}

The species have been arranged alphabatically following their scientific name, family name and local name of each species in tabular form. The treatment mode of the plants have been presented respectively.

\section{TABLE 1 : SPECIES NAME AND FAMILY WITH TREATMENT MODE}

\begin{tabular}{|c|c|c|c|}
\hline Scientific name & Local name & Family & Treatment mode \\
\hline Acanthus illicifolius $\mathrm{L}$. & Kekanta & Acanthaceae & $\begin{array}{l}\text { Juice prepared from the crushed roots with mixed } \\
\text { processed molasses (chakmitha) is taken in the } \\
\text { morning to treat waist pain. }\end{array}$ \\
\hline Achyranthes aspera $\mathrm{L}$. & Withlangda & Amaranthaceae & Roots are attached with ear to treat jaundice. \\
\hline $\begin{array}{l}\text { Aerva sanguinolenta }(\mathrm{L} .) \\
\text { Blume }\end{array}$ & Raktapata & Amaranthaceae & $\begin{array}{l}\text { Juice prepared from the crushed leaves is applied } \\
\text { in affected area to stop hemorrhages. }\end{array}$ \\
\hline Allium cepa $\mathrm{L}$. & Piaz & Liliaceae & $\begin{array}{l}\text { Juice prepared from the crushed bulbs is taken to } \\
\text { relieve cough. }\end{array}$ \\
\hline Allium sativum $\mathrm{L}$. & Rashun & Liliaceae & $\begin{array}{l}\text { Juice prepared from the crushed bulbs is taken to } \\
\text { treat cough. }\end{array}$ \\
\hline $\begin{array}{l}\text { Aphanamixis polystachya } \\
\text { (Wall.)Parker }\end{array}$ & Rona & Meliaceae & $\begin{array}{l}\text { Barks are steeped in water overnight and the } \\
\text { prepared extract is taken in the morning to relieve } \\
\text { jaundice. }\end{array}$ \\
\hline $\begin{array}{l}\text { Blumea lacera } \\
\text { (Burm.f.)DC. }\end{array}$ & Kormuta & Asteraceae & $\begin{array}{l}\text { Juice prepared from the crushed leaves is applied } \\
\text { to stop hemorrhages. }\end{array}$ \\
\hline Bombax ceiba L. & Tula & Bombacaceae & Root is applied to head to treat headache. \\
\hline $\begin{array}{l}\text { Bothriochloa pertusa (L.) } \\
\text { A. Camus }\end{array}$ & Ramdupa & Poaceae & $\begin{array}{l}\text { Juice prepared from the crushed leaves is taken to } \\
\text { treat piles. }\end{array}$ \\
\hline Brassica napus L. & Horra & Brassicaceae & $\begin{array}{l}\text { Oil of seed mixed with lime is applied in the child } \\
\text { body to relieve pain. }\end{array}$ \\
\hline $\begin{array}{l}\text { Cajanus cajan (L.) } \\
\text { Millsp. }\end{array}$ & Arol & Papilionaceae & $\begin{array}{l}\text { Juice prepared from the crushed leaves is taken to } \\
\text { relieve pain caused from dog bite. }\end{array}$ \\
\hline $\begin{array}{l}\text { Calotropis gigantea (L.) } \\
\text { Ait. f. }\end{array}$ & Akkan & Asclepiadaceae & $\begin{array}{l}\text { A warm leaf is applied to affected areas to treat } \\
\text { rheumatism. }\end{array}$ \\
\hline Cassia fistula $\mathrm{L}$. & $\begin{array}{l}\text { Sonamukhi } \\
\text { pata }\end{array}$ & Caesalpiniaceae & $\begin{array}{l}\text { Juice prepared from the crushed leaves is taken to } \\
\text { treat fever. }\end{array}$ \\
\hline $\begin{array}{l}\text { Catharanthus } \\
\operatorname{roseus}(\mathrm{L} .) \mathrm{G} \text {. Don }\end{array}$ & Nayantara & Apocynaceae & $\begin{array}{l}\text { Juice prepared from the crushed leaves is taken to } \\
\text { treat high blood pressure. }\end{array}$ \\
\hline $\begin{array}{l}\text { Centella asiatica } \\
\text { (L.)Urban. }\end{array}$ & Adamkipata & Apiaceae & $\begin{array}{l}\text { Juice prepared from the crushed leaves is applied } \\
\text { in eye to relieve eye infection. Young leaves are } \\
\text { taken to treat dysentery. }\end{array}$ \\
\hline Chenopodium album $\mathrm{L}$. & Battashak & Chenopodiaceae & $\begin{array}{l}\text { Breast pain of women is reduced by eating cooked } \\
\text { leaves. }\end{array}$ \\
\hline
\end{tabular}




\section{S B UDDIN et al.}

Cinnamomum tamala J.
Presl
Cinnamomum verum J.
Presl
Cissus qudrangularis $\mathrm{L}$.
Citrus aurantifolia
(Christm.) Swingle
Clerodendrum
infortunatum Gaertn.
Coccinea cordifolia
(L.)Cogn.
Cocos nucifera $\mathrm{L}$.

Tejpata

Darochini

Lauraceae

Lauraceae

Harvangalata

Vitaceae

Kagoji

Rutaceae

Bite

Kelakachu

Verbenaceae

Cucurbitaceae

Narkel

Arecaceae

Coix lacryma-jobi $\mathrm{L}$

Commelina benghalensis $\mathrm{L}$.

Coriandrum sativum L.

Curcuma longa $\mathrm{L}$.

Cuscuta reflexa Roxb.

Cynodon dactylon (L.)

Pers.

Dalbergia sissoo DC. Datura metel Sims.

Desmodium triflorum

(L.)DC.

Eclipta prostrata (L.) L.

Heliotropium indicum L.

Hibiscus rosa-sinensis L.

Hyptis suaveolens (L.)

Poit.

Ipomoea crossicaulis (Benth.)Roxb.
Hatishura

Opul pata

Tokma

\section{Sada Hongais Poaceae}

Kanaialata

Donna pata

Halud

Sunnalata

Dubla kher

Sisu

Dutra

Dudda lata

Kalakeccha

Papilionaceae

Asteraceae

Boraginaceae

Malvaceae

Lamiaceae

Dulkolmi

Convolvulaceae
Hot infusion of leaves is taken to relieve from fever.

Hot infusion of barks is taken to treat fever.

Stem is applied in affected area to treat fracture.

Crushed fruit is inhaled to treat cough.

Juice prepared from the crushed leaves is taken in the morning to treat jaundice and spermatorrhoea. Juice prepared from the crushed leave is taken to treat diabetes.

Green coconut water is taken to treat headache. Some religious rules are followed before taken it. It also applied in affected area to treat chicken pox.

Seed is steeped in water for six hours and the prepared extract is taken as tonic.

Paste prepared from the crushed leaves is applied to affected areas to treat boils

Seed is steeped in water for overnight and the prepared extract is taken to treat dysentery.

Paste prepared from rhizome is applied to treat skin diseases.

Juice prepared from the crushed plant is taken in the morning to treat gastritis.

Juice prepared from the crushed leaves is applied to stop hemorrhage.

Leaves are given to the cow to treat dysentery. Leaves are applied directly to the affected area to treat rheumatism.

Juice prepared from the crushed stem and leaves is taken to treat dysentery.

Juice prepared from the crushed leaves is taken in the morning to clean the blood and to treat bronchitis. It also applied as hair tonic.

Juice prepared from the crushed leaves is taken to increase breast milk in mother.

Juice prepared from the leaves is taken to treat irregular menstrual cycle.

Seed is steeped in water for overnight and the prepared extract is taken in the morning to treat heart disease.

Latex is applied in affected area to treat skin diseases. 


\section{INVESTIGATION OF ETHNOMEDICINAL PLANTS OF SUBARNACHAR IN NOAKHALI, BANGLADESH}

\begin{tabular}{|c|c|c|c|}
\hline Justicia adhatoda L. & Basak & Acanthaceae & $\begin{array}{l}\text { Juice prepared from the crushed leaves is taken } \\
\text { for the treatment of cough. }\end{array}$ \\
\hline Justicia ganderusa $\mathrm{L}$. & Bisdulmi & Acanthaceae & Leaves are given to cattle to treat diarrhoea. \\
\hline $\begin{array}{l}\text { Kalanchoe pinnata } \\
\text { (Lam.)Pers. }\end{array}$ & Thanda pata & Crassulaceae & $\begin{array}{l}\text { Juice prepared from the crushed leaves is applied } \\
\text { to treat headache. }\end{array}$ \\
\hline $\begin{array}{l}\text { Lablab purpureus } \\
\text { (L.)Sweet }\end{array}$ & Choi & Papilionaceae & $\begin{array}{l}\text { Seed is applied in affected area to relieve pain } \\
\text { caused by string fish. }\end{array}$ \\
\hline $\begin{array}{l}\text { Lannea coramandelica } \\
\text { (Houtt.)Merr. }\end{array}$ & Badi & Anacardiaceae & $\begin{array}{l}\text { Barks are steeped in water for overnight and the } \\
\text { prepared extract is taken in the morning to treat } \\
\text { jaundice. }\end{array}$ \\
\hline Lawsonia inermis $\mathrm{L}$. & Methi & Lythraceae & $\begin{array}{l}\text { Juice prepared from the crushed leaves is taken to } \\
\text { treat fever. }\end{array}$ \\
\hline $\begin{array}{l}\text { Lippia nodiflora }(\mathrm{L} .) \\
\text { michaux }\end{array}$ & Horina & Verbenaceae & $\begin{array}{l}\text { Juice prepared from the crushed leaves is taken to } \\
\text { treat paralysis. }\end{array}$ \\
\hline $\begin{array}{l}\text { Litsea monopetala } \\
\text { (Roxb.)Pers. }\end{array}$ & Medda pata & Lauraceae & $\begin{array}{l}\text { Juice is prepared from the crushed leaves is taken } \\
\text { to treat dysentery. }\end{array}$ \\
\hline Mangifera indica $\mathrm{L}$. & Aam & Anacardiaceae & $\begin{array}{l}\text { Juice prepared from the crushed leaves is taken to } \\
\text { treat gastritis. It is also used to reduce fat from the } \\
\text { body. }\end{array}$ \\
\hline Mikania scandens Willd. & Hakistani pata & Asteraceae & $\begin{array}{l}\text { Juice prepared from the crushed leaves is taken in } \\
\text { the morning to treat gastritis. }\end{array}$ \\
\hline Mimosa pudica $\mathrm{L}$. & Sorminda & Mimosaceae & $\begin{array}{l}\text { Root is attached in waist of child in Saturday and } \\
\text { Tuesday in a week to treat nocturnal enuresis. }\end{array}$ \\
\hline $\begin{array}{l}\text { Momordica charantia } \mathrm{L} . \\
\text { var. charantia } \mathrm{C} \text {. B. } \\
\text { Clarke }\end{array}$ & Korolla & Cucurbitaceae & $\begin{array}{l}\text { Tablet prepared from dried leaves and fruits are } \\
\text { taken to control diabetes. }\end{array}$ \\
\hline Musa acuminata Colla & Anajikola & Musaceae & $\begin{array}{l}\text { Juice prepared from the crushed roots is taken to } \\
\text { treat piles. }\end{array}$ \\
\hline Musa paradisiaca $\mathrm{L}$. & Bangla kola & Musaceae & Latex of flower is taken directly to treat dysentery. \\
\hline $\begin{array}{l}\text { Musa sapientum L. var. } \\
\text { sylvestrics }\end{array}$ & Aittakola & Musaceae & Cooked young fruit is taken to treat diarrhea. \\
\hline Ocimum sanctum $\mathrm{L}$. & Tulsi & Lamiaceae & $\begin{array}{l}\text { Juice prepared from the crushed leaves is taken to } \\
\text { treat cough. }\end{array}$ \\
\hline Opuntia dilleni Haw. & Sapgas & Cactaceae & $\begin{array}{l}\text { The plant is planted in cow-shade to remove away } \\
\text { snake. }\end{array}$ \\
\hline Oroxylum indicum Vent. & Thona & Bignoniaceae & $\begin{array}{l}\text { Bark are steeped in water overnight and the } \\
\text { prepared extract is taken in the morning to treat } \\
\text { jaundice. }\end{array}$ \\
\hline $\begin{array}{l}\text { Phoenix sylvestris (L.) } \\
\text { Roxb. }\end{array}$ & Khejur & Arecaceae & $\begin{array}{l}\text { Juice prepared from the crushed root of seedling is } \\
\text { taken to treat fever. }\end{array}$ \\
\hline
\end{tabular}




\section{S B UDDIN et al.}

\begin{tabular}{|c|c|c|c|}
\hline $\begin{array}{l}\text { Phyllanthus acidus } \\
\text { (L.)Skiels }\end{array}$ & Horoli & Euphorbiaceae & $\begin{array}{l}\text { Barks are steeped in water overnight and the } \\
\text { prepared extract is taken to treat skin diseases. }\end{array}$ \\
\hline Phyllanthus emblica L. & Amloki & Euphorbiaceae & $\begin{array}{l}\text { Fruit is taken to treat fever. It also taken as } \\
\text { refrigerant and tonic. }\end{array}$ \\
\hline Piper betel $\mathrm{L}$. & Pan & Piperaceae & $\begin{array}{l}\text { A warm leaf is applied to treat rheumatism. Juice } \\
\text { prepared from the crushed leaves is applied to } \\
\text { stop hemorrhages. }\end{array}$ \\
\hline Plantago major L. & Yusuf gul & Asteraceae & $\begin{array}{l}\text { Seed is steeped in water for overnight and the } \\
\text { prepared extract is taken in the morning to treat } \\
\text { heart disease and constipation. }\end{array}$ \\
\hline Portulaca oleracea $\mathrm{L}$. & Khet kalmi & Portulacaceae & $\begin{array}{l}\text { Juice prepared from } t \text { he crushed leaves is taken to } \\
\text { treat urinary tract infection. }\end{array}$ \\
\hline $\begin{array}{l}\text { Randia dumetorum } \\
\text { Lamk. }\end{array}$ & Mon gas & Rubiaceae & Root is attached in body to relieve anxiousness. \\
\hline $\begin{array}{l}\text { Rauvolfia serpentina (L.) } \\
\text { Benth. ex Kurz }\end{array}$ & Sarpagandha & Apocynaceae & $\begin{array}{l}\text { Juice prepared from the crushed leaves is taken to } \\
\text { treat depression. }\end{array}$ \\
\hline $\begin{array}{l}\text { Rhynchostylis retusa } \\
\text { (L.)Blume. }\end{array}$ & Koe gas & Orchidaceae & $\begin{array}{l}\text { Root is applied in the neck of children to treat } \\
\text { vomiting. It also collected in Saturday and } \\
\text { Tuesday. }\end{array}$ \\
\hline Santalum album $\mathrm{L}$. & Chandan & Santalaceae & $\begin{array}{l}\text { Stem is applied in the affected area to treat skin } \\
\text { diseases. }\end{array}$ \\
\hline Senna alata (L.)Roxb. & Daud & Caesalpiniaceae & $\begin{array}{l}\text { Juice prepared from the crushed leaves is applied } \\
\text { to affected area for the treatment of skin disease. }\end{array}$ \\
\hline Sesamum indicum $\mathrm{L}$. & Til & Pedaliaceae & $\begin{array}{l}\text { Oil obtained from seeds is used to rub for the } \\
\text { treatment of bodyache. Oil warmed and then } \\
\text { cooled is applied to affected areas in burnt. }\end{array}$ \\
\hline Spilanthes acmella L. & Moriccha lata & Asteraceae & Flower is applied in teeth to relieve dental pain. \\
\hline $\begin{array}{l}\text { Stephania harnandifolia } \\
\text { Walp. }\end{array}$ & Musoni pata & Menispermaceae & $\begin{array}{l}\text { Paste prepared from the crushed leaves is applied } \\
\text { as rubbing in head to treat headache. }\end{array}$ \\
\hline Sterculia foetida $\mathrm{L}$. & Keron & Sterculiaceae & $\begin{array}{l}\text { Juice prepared from the crushed leaves is taken to } \\
\text { treat diarrhea. }\end{array}$ \\
\hline $\begin{array}{l}\text { Swertia chirata } \\
\text { (Wall.)C.B.Clarke. }\end{array}$ & Chirpata & Gentianaceae & $\begin{array}{l}\text { Juice prepared from the crushed leaves is taken to } \\
\text { treat fever. }\end{array}$ \\
\hline $\begin{array}{l}\text { Syzygium cumini (L.) } \\
\text { Skeels }\end{array}$ & Butigajam & Myrtaceae & $\begin{array}{l}\text { Juice prepared from the crushed leaves is taken in } \\
\text { the morning to treat jaundice. }\end{array}$ \\
\hline Syzygium fruticosum DC. & Kowya gajam & Myrtaceae & $\begin{array}{l}\text { Juice prepared from the crushed leaves is taken in } \\
\text { the morning to treat jaundice. }\end{array}$ \\
\hline Tamarindus indica $\mathrm{L}$. & Tetul & Caesalpiniaceae & $\begin{array}{l}\text { Leaves are boiled and the prepared extract is taken } \\
\text { as antibilious. }\end{array}$ \\
\hline Terminalia arjuna Bedd. & Arjun & Compretaceae & $\begin{array}{l}\text { Barks are steeped in water overnight and the } \\
\text { prepared extract is taken in the morning to treat } \\
\text { jaundice and heart disease. }\end{array}$ \\
\hline $\begin{array}{l}\text { Terminalia bellirica } \\
\text { (Gaertner) Roxb. }\end{array}$ & Bahera & Compretaceae & Fruits are taken to treat fever. \\
\hline $\begin{array}{l}\text { Terminalia chebula } \\
\text { (Gaertner) Retz. }\end{array}$ & Horitoki & Compretaceae & Fruits are taken to treat fever. \\
\hline $\begin{array}{l}\text { Thespesia populnea }(\mathrm{L} .) \\
\text { Soland. ex Correa }\end{array}$ & Boly & Malvaceae & $\begin{array}{l}\text { Bark is steeped in water for overnight and the } \\
\text { prepared extract is taken to treat dysentery. }\end{array}$ \\
\hline
\end{tabular}




\section{INVESTIGATION OF ETHNOMEDICINAL PLANTS OF SUBARNACHAR IN NOAKHALI, BANGLADESH}

\begin{tabular}{|c|c|c|c|}
\hline Tribulus terrestris L. & Gakkur & Zygophyllaceae & $\begin{array}{l}\text { Spine is steeped in water overnight and the } \\
\text { prepared extract is taken in the morning to treat } \\
\text { heart disease. }\end{array}$ \\
\hline Vitex negundo L. & Ninda & Verbenaceae & $\begin{array}{l}\text { Juice prepared from the crushed leaves is applied } \\
\text { as hair tonic. }\end{array}$ \\
\hline $\begin{array}{l}\text { Wedelia chinensis } \\
\text { (Osbeck) Merr. }\end{array}$ & Bhimraj & Asteraceae & $\begin{array}{l}\text { Juice prepared from the crushed leaves is taken to } \\
\text { treat fever. }\end{array}$ \\
\hline $\begin{array}{l}\text { Withania somnifera } \\
\text { Dunal. }\end{array}$ & Arshagondha & Solanaceae & $\begin{array}{l}\text { Seed is steeped in water overnight and the } \\
\text { prepared extract is taken to relieve heart disease. }\end{array}$ \\
\hline $\begin{array}{l}\text { Zingiber officinale } \\
\text { Roscoe. }\end{array}$ & Ada & Zingiberaceae & $\begin{array}{l}\text { Juice prepared from the crushed rhizome is taken } \\
\text { to treat gastritis and to relieve cough. }\end{array}$ \\
\hline $\begin{array}{l}\text { Zizyphus mauritiana } \\
\text { Lamk. }\end{array}$ & Baroi & Rhamnaceae & $\begin{array}{l}\text { Juice prepared from the crushed leaves is taken in } \\
\text { the morning to treat jaundice. }\end{array}$ \\
\hline
\end{tabular}

A total of 84 ethnomedicinal plant species under 75 genera in 47 families have been documented from the informants which are used for the treatment of 34 diseases/illness. According to life form the numbers of species have been used by them are herbs $35 \%$, shrubs $24 \%$, trees $32 \%$, and climber 9\% respectively (Fig 1). The most utilized plant parts for the preparation of herbal medicine is leaf which is $50 \%$, then root $9.52 \%$, seed $8.33 \%$, bark $8.33 \%$, fruit $8.33 \%$, stem $3.57 \%$, bulb $2.38 \%$, whole plant $2.38 \%$, rhizome $2.38 \%$, latex $2.38 \%$, flower $1.19 \%$ and spine $1.19 \%$ respectively.

The study revealed that root and the whole plant have been used in preparation of herbal medicine is $2.38 \%$ for the treatment of disease/illness. These are the destructive way of using plants because it needs to destroy or uproot the whole plant. But leaf, fruit, flower or other aerial parts can be used without destroying the plant. So, using the plant parts without destroying the plant is a significant way to conserve them. 
S B UDDIN et al.

\section{Percentage}

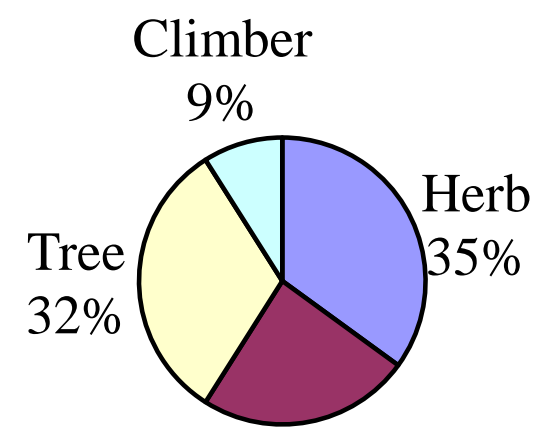

FIG 1: PERCENTAGE OF HERB, SHRUB, TREE AND CLIMBER USED BY THE SUBARNACHAR PEOPLE FOR THEIR PREPARATION OF MEDICINE.

The recorded ethnomedicinal plant species have been used to treat several diseases/illness (Fig 2) of which $13.33 \%$ are used for the treatment of various type of pain, $10 \%$ for jaundice, $6.67 \%$ for cough, $4.44 \%$ for hemorrhages, $3.33 \%$ for rheumatism, $5.56 \%$ skin disease, $10 \%$ for fever, $7.78 \%$ for dysentery, $4.44 \%$ for tonic, $4.44 \%$ for gastric, $5.56 \%$ for heart disease, $3.33 \%$ for diarrhea and $21.11 \%$ for others.

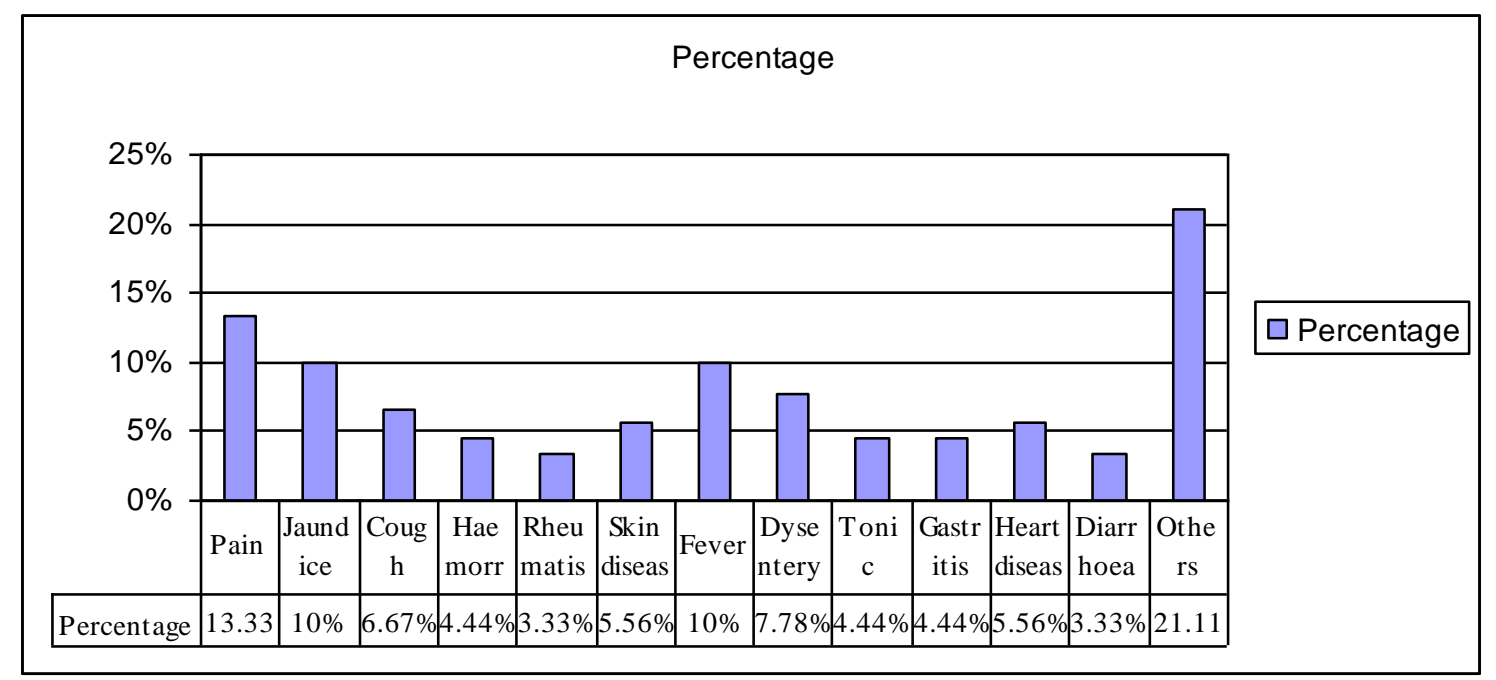

FIG 2: PLANT USED FOR VARIOUS DISEASES/ILLNESS BY THE SUBARNACHAR PEOPLE. 
INVESTIGATION OF ETHNOMEDICINAL PLANTS OF SUBARNACHAR IN NOAKHALI, BANGLADESH

The most frequently preparatory methods of herbal medicine are juice, extract, paste, tablet/pills, ash, sap etc. Both external and internal methods of application of herbal medicine have been prescribed. The internal use of herbal medicine is $67.82 \%$ where as the external use is $32.18 \%$.

The dose and duration of application of these medicinal preparations are varied from informant to informant and on the basis of disease/illness. Time of taking medicine is also varied.

The establishment of modern medicinal health centre is in progress in many rural areas and that may gradually change the existing pattern of indigenous knowledge system of healthcare. Now a days they are loosing their previous glorious heritage of plant use knowledge in an alarming rate because of, industrialization and urbanization, excessive collection, habitat destruction, agricultural advancement, present generation lost the interest to continue their parental profession because it does not provide them proper financial support for their livelihood, local herbalists and elderly men /women in these areas find it very difficult to get apprentices to meet their several necessities etc. It is very urgent to document these plant use information before their lost forever.

\section{ACKNOWLEDGEMENT}

The authors express their deep sense of gratitude to the informants and the local men and women who helped them in many different ways during the field work. Authors are grateful to Prof. Dr. M K Pasha, Department of Botany for his valuable suggestions and criticism during preparing this manuscript and to identify some critical specimens. Authors are also grateful to Dr. Labina Akther, Medical Officer, Chattagram Maa-Shishu O General Hospital, Chittagong for her help in identifying some diseases.

\section{REFERENCES}

AHMED, Z.U., BEGUM, Z.N.T., HASSAN, M.A., KHONNDKER, M., KABIR, S.M.H., AHMAD, M. AND AHMED, A.T.A. (eds.). 2008. Encyclopedia of Flora and Fauna of Bangladesh, Vol. 6. Angiosperms: Dicotyledons (Acanthaceae-Asteraceae). Asiatic Society of Bangladesh, Dhaka. 408 pp. 
S B UDDIN et al.

AHMED, Z.U., HASSAN, M.A., BEGUM, Z.N.T., KHONNDKER, M., KABIR, S.M.H., AHMAD, M. AND AHMED, A.T.A. (eds.). 2008. Encyclopedia of Flora and Fauna of Bangladesh, Vol. 7. Angiosperms: Dicotyledons (Balsamaniaceae-Euphorbiaceae). Asiatic Society of Bangladesh, Dhaka. $546 \mathrm{pp}$.

AHMED, Z.U., HASSAN, M.A., BEGUM, Z.N.T., KHONNDKER, M., KABIR, S.M.H., AHMAD, M. AND AHMED, A.T.A., RAHMAN, A.K.A. AND HAQUE, E.U.(eds.). 2009. Encyclopedia of Flora and Fauna of Bangladesh, Vol. 8. Angiosperms: Dicotyledons (Fabaceae-Lythraceae). Asiatic Society of Bangladesh, Dhaka. 478 pp.

AHMED, Z.U., HASSAN, M.A., BEGUM, Z.N.T., KHONNDKER, M., KABIR, S.M.H., AHMAD, M. AND AHMED, A.T.A. (eds.). 2009. Encyclopedia of Flora and Fauna of Bangladesh, Vol. 9. Angiosperms: Dicotyledons (Magnoliaceae-Punicaceae). Asiatic Society of Bangladesh, Dhaka. 488 pp.

AHMED, Z.U., HASSAN, M.A., BEGUM, Z.N.T., KHONNDKER, M., KABIR, S.M.H., AHMAD, M. AND AHMED, A.T.A. (eds.). 2009. Encyclopedia of Flora and Fauna of Bangladesh, Vol. 10. Angiosperms: Dicotyledons (Ranunculaceae-Zygophyllaceae). Asiatic Society of Bangladesh, Dhaka. $580 \mathrm{pp}$.

ALEXIADES, M.N. 1996. Protocol for conducting ethnobotanical research in the tropics. In: Alexiades, M.N. \& J.W. Sheldon (eds.) Selected Guidelines for Ethnobotanical Research: A Field Manual. The New York Botanical Garden, Bronx, New York. 306 PP

HASSAN, M.A.1971. Bangladesher Owshudhi Gasgasra. Hasan Book House, Dhaka, Bangladesh. 198 PP

HEINIG, R.L. 1925. List of plants of Chittagong Collectorate and Hill tracts. Darjeeling. pp. 1-84.

HOOKER, J.D. 1872-1897. The Flora of British India Ind. Repr. 1973, Bishen Singh Mahendra Pal Singh, Dehra Dun, India. Vol. 1-7 : 740-5568

MAHMUD, A.K.M.G. 2007. Shamvabonamoye Subarnachar (In Bangla). The M. A. Salam Publishers. Bangla Bazar, Dhaka. pp 13-27.

PRAIN, D. 1903. Bengal Plants. Reprint Edition 1963. Calcutta. Vol. 1 and 2. : 1013

Manuscript received on 22.10.2011; Accepted on 07.07.2012

The Chittagong University Journal of Biological Sciences, Vol. $6(1 \& 2)$. Page No. 